\title{
Basic Surface Properties of Mononuclear Cells from Didelphis marsupialis
}

\author{
Valéria Pereira Nacife/ ${ }^{+}$, Maria de Nazareth Leal de Meirelles, \\ Fernando Costa e Silva Filho*
}

\begin{abstract}
Laboratório de Ultra-estrutura Celular, Instituto Oswaldo Cruz, Av. Brasil 4365, 21045-900 Rio de Janeiro, RJ, Brasil *Instituto de Biofísica Carlos Chagas Filho - UFRJ, CCS- Bloco G, 21949-900 Rio de Janeiro, RJ, Brasil

The electrostatic surface charge and surface tension of mononuclear cells/monocytes obtained from young and adult marsupials (Didelphis marsupialis) were investigated by using cationized ferritin and colloidal iron hydroxyde, whole cell electrophoresis, and measurements of contact angles. Anionic sites were found distributed throughout the entire investigated cell surfaces. The results revealed that the anionic character of the cells is given by electrostatic charges corresponding to $-18.8 \mathrm{mV}$ (cells from young animals) and $-29.3 \mathrm{mV}$ (cells from adult animals). The surface electrostatic charge decreased from 10 to $65.2 \%$ after treatment of the cells with each one of trypsin, neuraminidase and phospholipase $C$. The hydrophobic nature of the mononuclear cell surfaces studied by using the contact angle method revealed that both young and adult cells possess cell surfaces of high hidrofilicity since the angles formed with drops of saline water were $42.5^{\circ}$ and $40.8^{\circ}$, respectively. Treatment of the cells with trypsin or neuraminidase rendered their surfaces more hydrophobic, suggesting that sialic acid-containing glycoproteins are responsible for most of the hydrophilicity observed in the mononuclear cell surfaces from D. marsupialis.
\end{abstract}

Key words: monocytes - cell surface - surface charge - surface tension - Didelphis marsupialis

The cell surface of monocytes, as in other eucaryotic cells, is characterized by the presence of surface associated glyco- and mucoproteins, most of them containing sialic acid residues. Such surface coat plays an important role in cell-cell and cell-substrate interaction processes (Cook 1986, Lamb et al. 1995, Torroba et al. 1995). The surface-exposed carbohydrates can be evidentiated at the ultrastructural level by using several eletrondense markers, such as rutenium red (Luft 1971) and cationized ferritin (Danon et al. 1972, Grinnell et al. 1976).

Most of the terminal carbohydrates of the saccharidic side chains of glycoconjugates are sialic acids, usually furnishing a net negative charge to the cell surface (Rambourg 1971), and the values of such negativeness varying according to the number and charge of the exposed ions (Mutsaers \&

\footnotetext{
This work was supported by Conselho Nacional de Desenvolvimento Científico e Tecnológico (CNPq/ PADCT), Fundação Oswaldo Cruz, Financiadora de Estudos e Projetos (Finep), and the Third World Academy of Sciences.

${ }^{+}$Corresponding author. Fax: + 55-21-260.4434. E-mail: vnacife@gene.dbbm.fiocruz.br

Received 1 October 1997

Accepted 22 July 1998
}

Papadimitriov 1988). However, other anionic sites such as the phosphates of phospholipids and sulphates of mucopolysaccharides also contribute to the cell surface negativity, being their presence detected by diverse assays such as ultrastructural cytochemistry (Gasic et al. 1968, Danon et al. 1972), cell electrophoresis (Ambrose 1965, James 1979) and electrostatic interaction cromatography (Mozes \& Rouxhet 1987, Rouxhet \& Mozes 1990).

Other important surface property is the surface tension, usually known as hydrophobicity. This property results from the exposition of hydrophobic aminoacids in the glycoproteins. Its measurement is usually made by means of contact angle method (vanOss 1978) and X-ray photoelectronic spectroscopy (Mozes \& Rouxhet 1987).

In this work we investigate the surface charge of the mononuclear cells and monocytes of the opossum Didelphis marsupialis by ultrastructural cytochemistry, zeta potential, and contact angle measurements. Attempts are done in order to identify the involvement of some surface terminal residues in the studied properties.

\section{MATERIALS AND METHODS}

Animals - Fifteen wild adult opossums (D. marsupialis) weighting 900-1,500 g were trapped in Teresópolis and in the campus of the Universidade Federal Rural do Rio de Janeiro, State of Rio de Janeiro, Brazil. 
Opossums are recognized as important reservoir hosts for Chagas' disease, for this reason, control of Trypanosoma cruzi natural infection was done by parasitological (hemocultive and xenodiagnosis) and serological tests (Brener et al. 1974, Jansen et al. 1985). All animals were shown to be negative.

In some experiments, blood sample collected of pouch young animals (80-100 days old), from the marsupium of wild caught females, was used.

Collection of the mononuclear cells - Blood of adult animals was collected by heart puncture and centrifuged twice at $300 \mathrm{~g}$ for $20 \mathrm{~min}$ to remove platelets. The final pellet was diluted in 0.01 phosphate buffered saline (PBS) $0.85 \% \mathrm{NaCl}$ (I=0.145 mol. $\left.\mathrm{dm}^{-3} \mathrm{pH}=7.2\right)$ and applied to a Histopaque gradient $(\mathrm{d}=1077 \mu \mathrm{g} / \mathrm{ml})$ (Feldman \& Mogelesky 1987). The mononuclear fraction situated above the Histopaque cushion was collected, washed in PBS and used in the experiments.

Young animals were anesthetized with ether and decapited. The blood of this region was collected by punction with a syringe, diluted in PBS and applied to the Histopaque cushion, as above described.

Enzyme treatments - Cells of the mononuclear fraction were incubated with (a) neuraminidase of Vibrio cholera (Type X, Sigma Chemical Co., USA), $0.1 \mathrm{U} / \mathrm{ml}$, for $1 \mathrm{hr}$ at $37^{\circ} \mathrm{C}, \mathrm{pH}=6.0$; (b) trypsin (Sigma Chemical Co., USA), $500 \mu \mathrm{g} / \mathrm{ml}$, for $5 \mathrm{~min}$ at $37^{\circ} \mathrm{C}, \mathrm{pH}=7.0$; (c) phospholipase $\mathrm{C}$ of Bacillus cereus (Sigma Chemical Co., USA), 1 U/ $\mathrm{ml}$ for $1 \mathrm{hr}$ at $37^{\circ} \mathrm{C}, \mathrm{pH}=7.0$.

All enzymes were diluted in PBS. After incubation, the cells were washed twice in PBS and processed for ultrastructural cytochemistry (cationized ferritin), electrophoretic mobility determination and contact angle measurement.

Ultrastructural cytochemistry - Cells were fixed for $1 \mathrm{hr}$ at $4^{\circ} \mathrm{C}$ with $2.5 \%$ glutaraldehyde in $0.1 \mathrm{M}$ cacodylate buffer, $\mathrm{pH} 7.2$, washed in buffer, and then incubated with either cationized ferritin (100 $\mu \mathrm{g} / \mathrm{ml}, 1 \mathrm{hr}$ at room temperature) or colloidal iron solution, $\mathrm{pH} 1.8$ (30 min at room temperature). The cells were washed respectively with Tyrode solution or $12 \%$ acetic acid, and then post-fixed for 1 $\mathrm{hr}$ in $1 \% \mathrm{OsO}_{4}$ in $0.1 \mathrm{M}$ cacodylate buffer, $\mathrm{pH}$ 7.2. Thereafter, the cells were dehydrated in graded acetone and embedded in Epon. As controls, some cells were processed without incubation with the cationic particles.

In some experiments cells from adult animals were incubated with cationized ferritin for $20 \mathrm{~min}$ at $4{ }^{\circ} \mathrm{C}$, washed with Tyrode solution, and then processed for routine transmission electron microscopy.
Electrokinetical (Zeta) potential - Cells were washed in PBS, fixed with $2.5 \%$ glutaraldehyde, washed again in PBS and then introduced into a cell electrophoresis chamber. Zeta potencial was obtained (in mV) in a Pen Kem equipment, Model 501, at the following conditions: conductivity = $1.210 \mu \mathrm{mhos} . \mathrm{cm}^{-1}$; electric potential $=100 \mathrm{~V}$; temperature $=28.0 \pm 0.5^{\circ} \mathrm{C}$ (Silva Filho et al. 1990).

Surface tension - Surface tension was estimated by contact angle measurements (vanOss 1978). The cells were collected on Millipore filters, pore diameter $0.45 \mu \mathrm{m}$ and air dried for $1 \mathrm{hr}$. Contact angles were calculated in the air-liquid-cell interface tangence point. The following liquids were used: sodium chloride (highly hidrophilic), dimetilsulfoxide (DMSO) (slightly hidrophobic) and alpha-bromonaftalene (highly hidrophobic). Each value corresponds to the mean of 10 measurements (Silva Filho et al. 1990).

\section{RESULTS}

About $15-20 \mathrm{ml}$ of blood could be obtained from each young and adult opossum. After centrifugation in the Histopaque gradient, 3-4 x $10^{6}$ mononuclear cells (monocytes and lymphocytes) could be obtained per ml. From these cells 3 x $10^{5}(10 \%)$ corresponded to monocytes (data not shown).

Ultrastructural cytochemistry - Transmission electron microscopy of the mononuclear fraction showed the presence of monocytes as well as platelets, erytrocytes, lymphocytes and polymorphonuclear cells (Fig. 1).

Reaction with cationized ferritin appeared as a continuous layer of particles in the cell surface for monocytes young (Fig. 2a) and adult animals (Fig. 2b).

In adult animals cells incubated with cationized ferritin before the fixation with glutaraldehyde, the reaction appeared as patches on the cell surface (Fig. 3).

Further, incubation of the cells from adult animals with colloidal iron hydroxyde resulted in an uniform electrondense reaction on the whole cell surfaces (Fig. 4), however, cells from young animals showed a patch reaction (Fig. 5).

Zeta potential measurement - Mononuclear cells fractions obtained from adult animals presented a mean surface negativity corresponding to - $29.3 \mathrm{mV}$ (Table I). In monocyte-enriched fractions the surface negativity ranged from -22.0 to $25 \mathrm{mV}$ (data not shown).

Mononuclear cell fractions obtained from young animals presented a mean surface negativity of $-18.8 \mathrm{mV}$.

Enzyme treatments - Incubation of cells from adult animals with each one of trypsin, neuramini- 


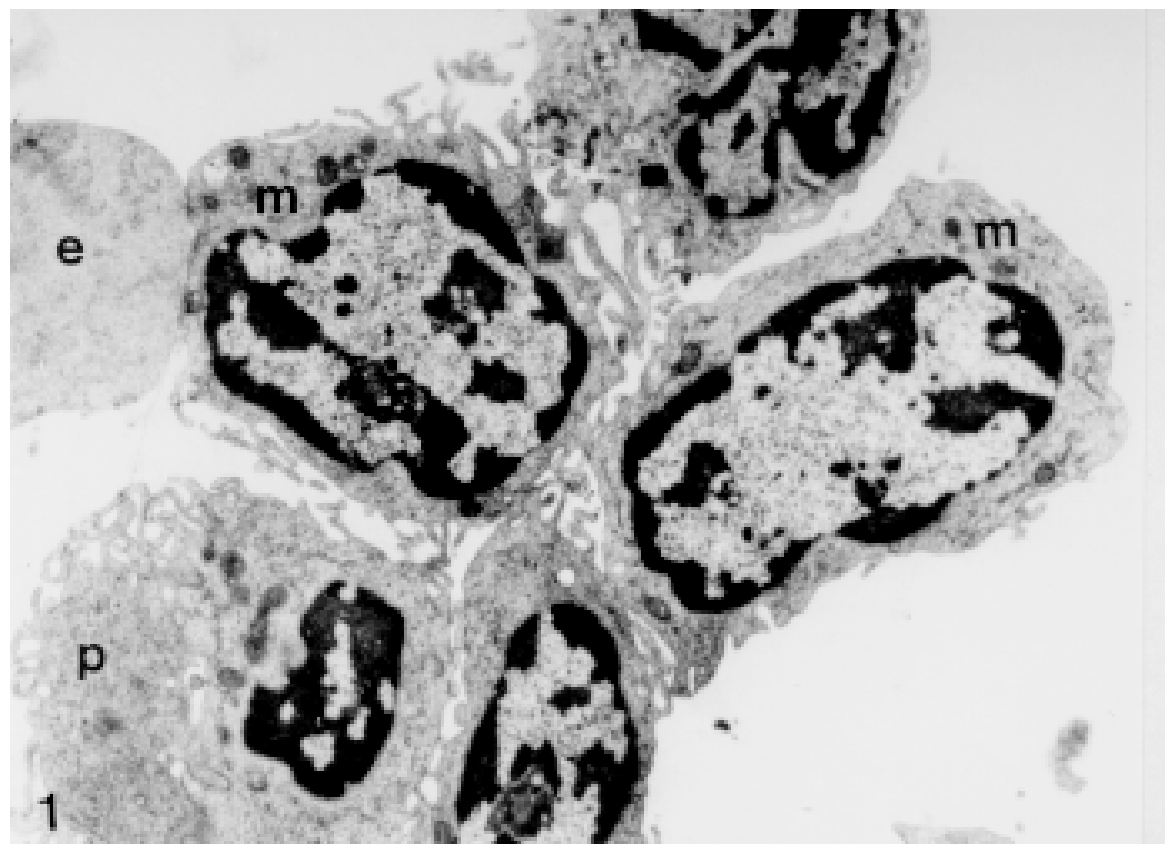

Fig. 1: general aspect of the mononuclear cells after collection from the Histopaque gradient. Some contaminants could be seen besides the monocytes $(\mathrm{m})$ as polymorphonuclear cells, erythrocytes (e) and platelets (p). 10. $000 \mathrm{X}$.

TABLE I

Effect of enzyme treatments on the electrokinetic potential of the enriched fraction in circulating monocytes of opossum

\begin{tabular}{lll}
\hline Treatment & Cells of young animals & Cells of adult animals \\
& $\mathrm{ZP} \pm \mathrm{SE}(\mathrm{mV})$ & $\mathrm{ZP} \pm \mathrm{SE}(\mathrm{mV})$ \\
\hline None & $-18.8 \pm 0.6$ & $-29.3 \pm 1.4$ \\
Neuraminidase & $-16.9 \pm 1.0(-10.2 \%)^{a}$ & $-16.1 \pm 2.5(-45.1 \%)$ \\
Trypsin & $-14.5 \pm 1.6(-22.9 \%)$ & $-10.2 \pm 1.2(-65.2 \%)$ \\
Phospholipase C & $-16.4 \pm 0.9(-12.8 \%)$ & $-13.3 \pm 2.1(-54.6 \%)$ \\
\hline
\end{tabular}

ZP: Zeta potential; SE: standard error; $a$ : values between parenthesis represent variations in the mean ZP were obtained from the following equation: $[(\mathrm{ZPc}-\mathrm{ZPt}): \mathrm{ZPc}]$ x 100, where the indexes " $\mathrm{c}$ " and " $\mathrm{t}$ " denotes control and enzyme treated cells.

dase and phospholypase $\mathrm{C}$ resulted in high decreases $(45-65 \%)$ of the zeta potential (Table I). Excepting the treatment with phospholipase $\mathrm{C}$ that did not alter the pattern of CF reactivity (Fig. 6) either neuraminidase as trypsin were able to reduce and abolish the reactivity of the cell surfaces with cationized ferritin (Figs 7, 8)

Surface tension - Contact angle measurements are summarized in Table II. The surface polarity of monocytes from both young and adult animals was compared in experiments using liquids of different polarities such as the high hydrophilic sodium chloride and the high hydrophobic a-bromonaphtalene.
Dimethylsulfoxide was also used in such experiments as a liquid of intermediary polarity. As can be seen in the Table II the data obtained from measurements made with drops of each liquid show that the monocytes from young animals are slightly more hydrophilic than the adults ones, since the contact angles obtained with a-bromonaphtalene were 45.8 (young) and 38.2 (adults) (Table II). Enzymatic treatments resulted in alterations in the contact angle values. While trypsin or neuraminidase induced similar alterations in the contact angle values, phospholipase $\mathrm{C}$ further increased such values in about $30^{\circ}$ (Table III). 

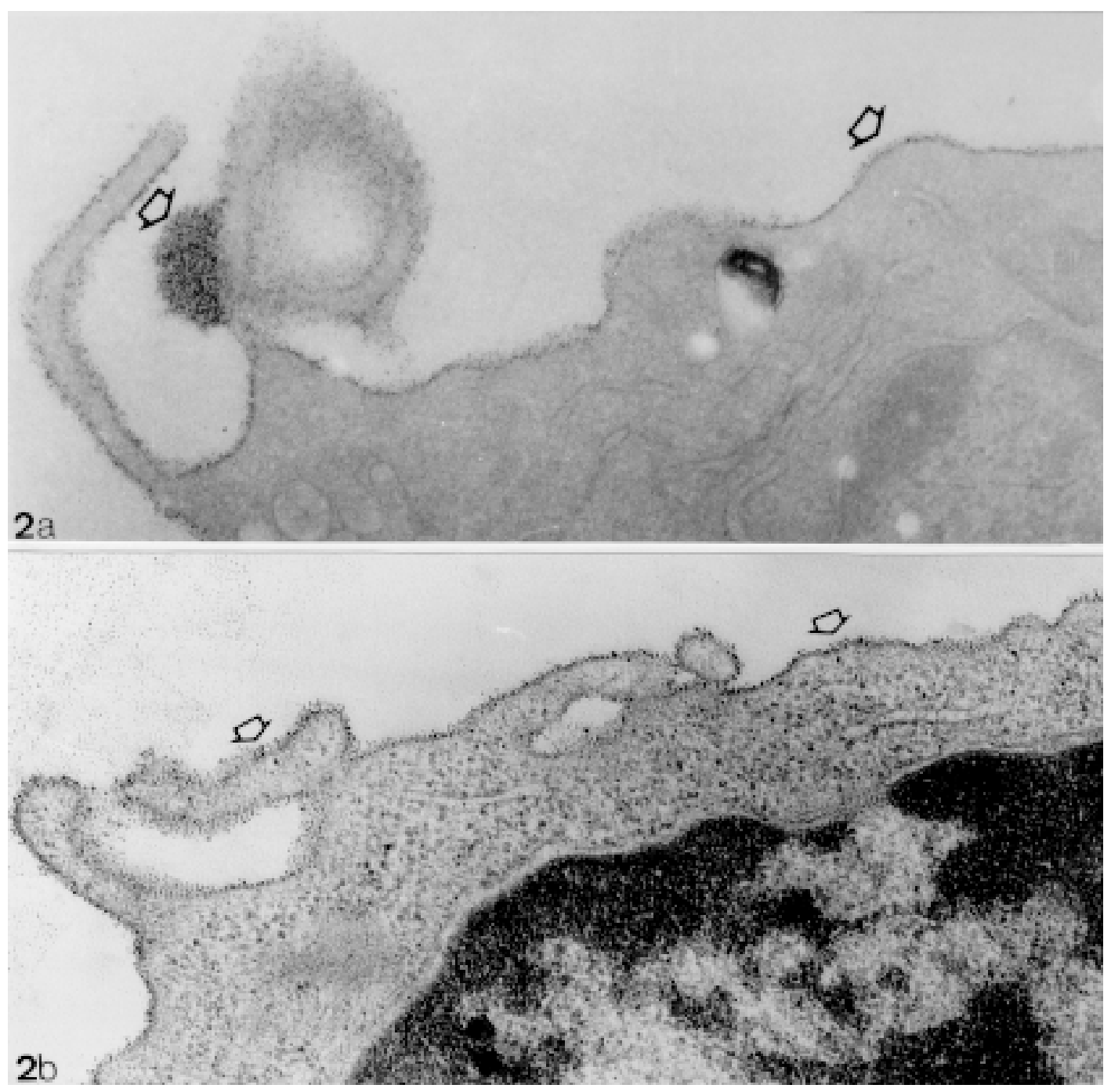

Fig. 2a: monocyte from the young opossum fixed at room temperature for $1 \mathrm{hr}$, incubated with cationized ferritin (CF) during the same time and observed without contrastation. The cells showed an uniform distribution of the CF particles over the whole surface and sometimes a patchy profile with several layers of CF particles could be found (arrow) $(61500 \mathrm{X})$. Fig. $2 \mathrm{~b}$ : monocytes from adult animals, fixed and incubated with CF in the same condition as the young animal were observed after stained with uranyl acetate and lead nitrate. An uniform distribution of the ferritin particles were seen in the whole surface of the mononuclear cells (arrows) $(64.000 \mathrm{X})$.

\section{TABLE II}

Measurements of contact angle of enriched fractions in monocytes

\begin{tabular}{lll}
\hline Liquid & $\begin{array}{l}\text { Cells of young } \\
\text { animals } \pm \mathrm{SE}^{\mathrm{q}}\end{array}$ & $\begin{array}{l}\text { Cells of adult } \\
\text { animals } \pm \mathrm{SE}^{\mathrm{q}}\end{array}$ \\
\hline Sodium chloride & $42.5 \pm 0.16^{a}$ & $40.8 \pm 0.21$ \\
a-Bromonaphtalene & $45.8 \pm 0.01$ & $38.2 \pm 0.15$ \\
DMSO & $28.9 \pm 0.02$ & $31.5 \pm 0.10$ \\
\hline
\end{tabular}

q: contact angle; SE: standard error; $a$ : mean values corresponding to ten individual measurements

\section{DISCUSSION}

This study is an attempt to obtain blood cell fraction from $D$. marsupialis in which monocytes are the predominant cell type. Circulating blood cells from either young or adult animals were centrifuged in each of Histopaque-1077 gradient, Ficoll-Hipaque, and Sepracell. By using Histopaque-1077, it was possible to obtain a large number of monocytes.

Anionic sites of the monocytes were detected 


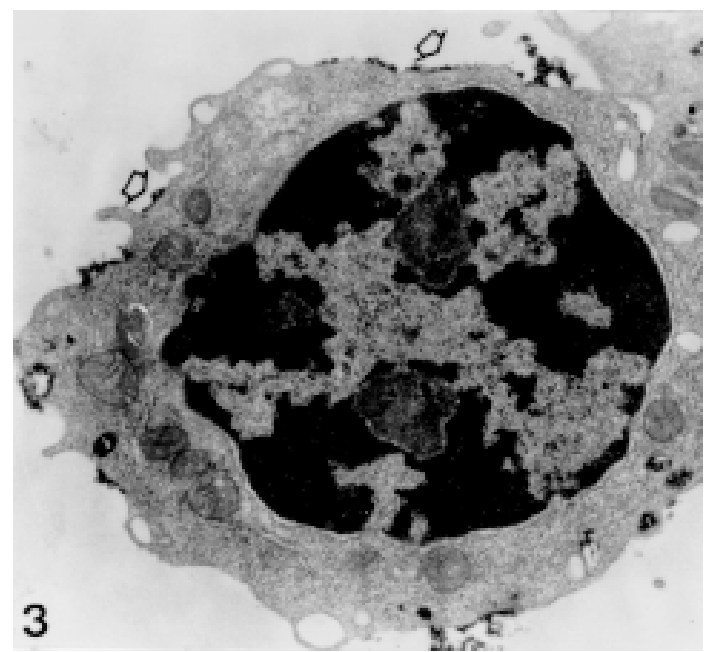

Fig. 3: mononuclear cells from adult opossum were incubated with cationized ferritin $(\mathrm{CF})$ at $4^{\circ} \mathrm{C}$ during $20 \mathrm{~min}$ and after they were fixed. $\mathrm{CF}$ particles showed a heterogeneous distribution in the surface (arrow) $(16.000 \mathrm{X})$.

at the ultrastructural level by incubating the cells with colloidal iron hydroxide and cationized ferritin particles. Both markers detected acidic carboxyl groups, such as those present in sialic acid, the main anionic component of glycoconjugates at the cell surface of erythrocytes.

This negative surface charge has been directly implicated in some important cellular activities, such as adhesion, spreading and endocytosis (vanOss 1978, Silva Filho et al. 1990). As surface charge and surface tension are basic cell properties dictating cell-cell interaction phenomenon we did decide to investigate such properties in the here
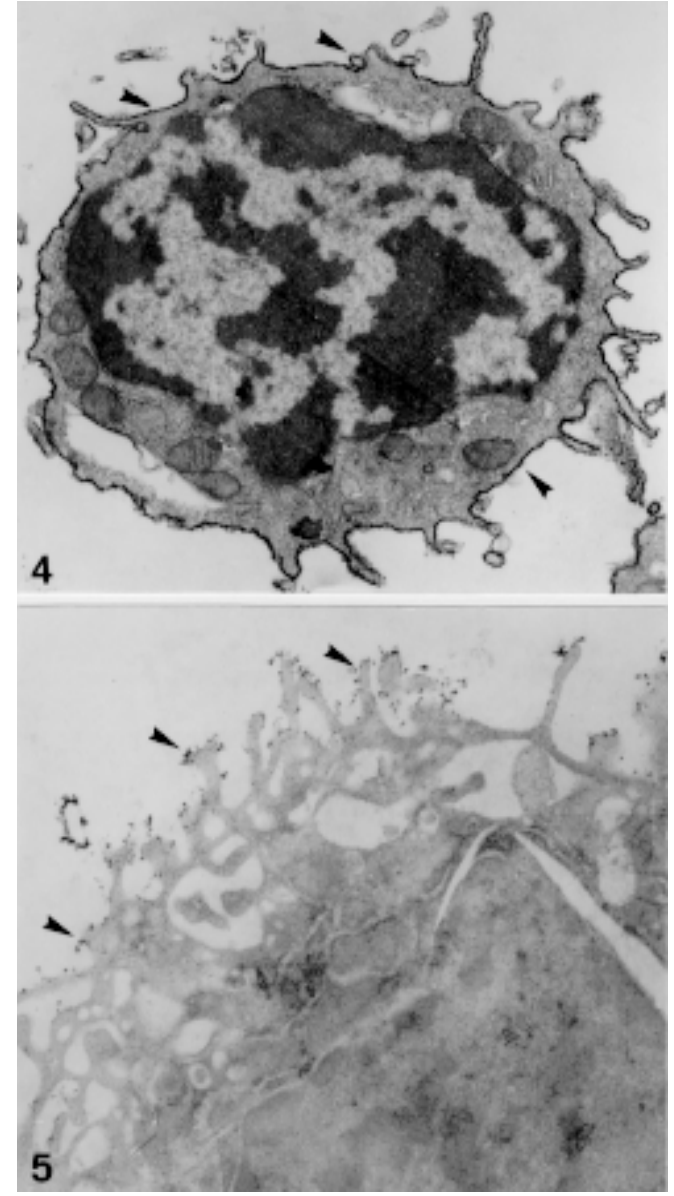

Treatment of the fixed monocyte cells with colloidal iron. Fig. 4: cells from adult opossum displayed an electrondense and uniform localization (arrowhead) (18.000 X). Fig. 5: cells from young animals showed a particulate reaction distributed at the cell surface (arrowhead) (18.500 X).

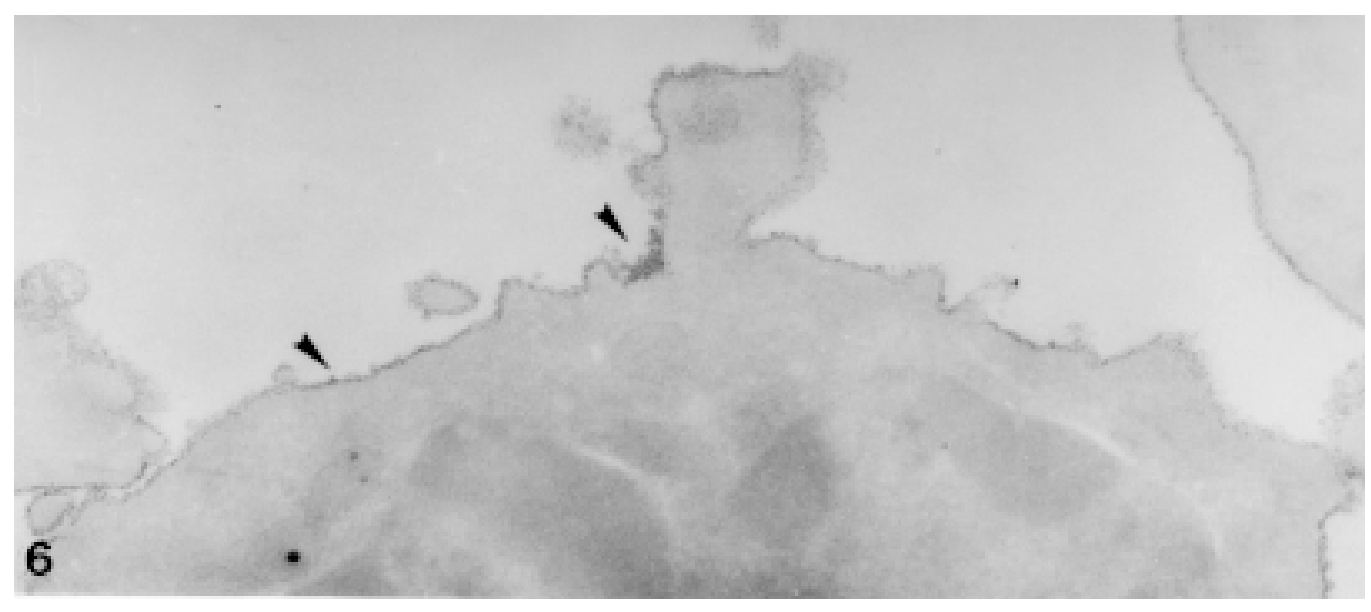

Fig. 6: after treatment with phospholipase $\mathrm{C}$, monocytes were fixed and incubated with cationized ferritin. The electrondense marker was seen regularly distributed over the entire surface of the cells (arrowhead) (24.000 X). 


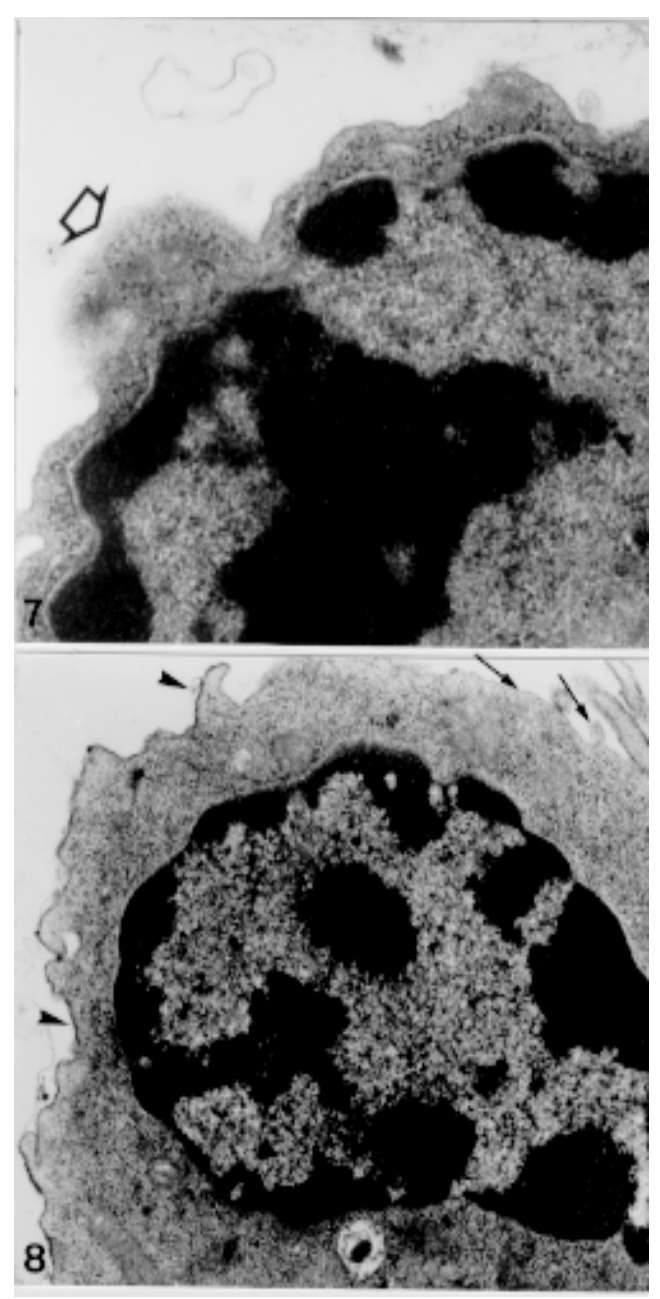

Fig. 7: monocyte cells of adult opossum were treated with trypsin, following fixation and incubation with cationized ferritin (large arrow). No reaction was observed at the surface of the cells (49.000 X). Fig. 8: treatment of the monocytes cells with neuraminidase. After fixation and incubation with cationized ferritin $(\mathrm{CF})$, cells showed an irregular distribution at the surface with some regions of the plasma membrane presenting the electrondense marker (arrowhead) and others completely devoid of CF (thin arrows) $(22.000 \mathrm{X})$. studied cells since monocytes- macrophages cells are directly involved in the phenomenon. Otherwise, surface negativeness of mice macrophages seems to be of high importance, during their interaction with procariote and eukariote pathogens (Silva Filho et al. 1987).

Firstly, attempts were done in order to investigate the topology of the surface anionic sites among young and adult cells. Cationic particles of ferritin and colloidal iron were used taken into mind that the first are able to reveal anionic species ionizable at physiological $\mathrm{pH}$ while the last mainly react with ionizable species revealed at very low $\mathrm{pH}$, such as carboxyls from extremely acidic species and sulphates from mucopolysacharides.

In order to exclude the possibility of the interference of the glutaraldehyde in the result labelling we performed assays in which chemical fixation was excluded. No significant differences could be observed in the cell surfaces which had been fixed or not with glutaraldehyde. However, as expected, non-fixed cells showed a patchy distribution of the anionic sites. It is important to point out that macrophages possess low degrees of membrane fluidity (Mutsaers \& Papadimimitriov 1988).

Thus, it seems that membrane fluidity may be altered during the differentiation of monocytes to macrophages. It is a hypothesis which deserves to be further investigated with the here investigated cells from the opossum. We did also observe that when colloidal iron particles were assayed most of the cells showing great labelling were from adult animals, suggesting that cell maturation can be also followed by alterations in surface charge. This seems to be in according to Akerman (1975) which were able to demonstrate a direct reaction between reactivity of hematopoietic cells to ferritin particles and maturation.

The nature of cell surface anionic sites was also a subject of investigation. Reactivity of the circulating monocytes to the cationic labels was analyzed after treatment of the cells with of trypsin,

\section{TABLE III}

Measurements of contact angle of cells obtained from young and adults animals with drops of $\mathrm{NaCl}$

\begin{tabular}{lll}
\hline Treatment & Cells of young animals \pm SE $^{q}$ & Cells of adult animals \pm SEq $^{q}$ \\
\hline None & $41.0 \pm 0.10^{a}$ & $42.3 \pm 0.20$ \\
Trypsin & $50.5 \pm 0.23(23.2 \%)^{b}$ & $52.8 \pm 0.15(24.8 \%)$ \\
Neuraminidase & $48.9 \pm 0.40(19.3 \%)$ & $50.7 \pm 0.10(19.9 \%)$ \\
Phospholipase C & $72.4 \pm 0.21(76.6 \%)$ & $70.4 \pm 0.20(66.4 \%)$ \\
\hline
\end{tabular}

q: contact angle; SE: standard error; $a$ : mean values corresponding to ten individual measurements; $b$ : percentual variations of contact angle between treated $(q t)$ and non treated $(q c)$ cells which were calculated from [(qc) - $(q t)$ : (qc)] x 100. 
neuraminidase and phospholipase C. In addition, an estimation of the surface negativeness of untreated and enzyme treated cells was performed by means of zeta potential measurements.

Treatment with neuraminidase did not affect reactivity with cationized ferritin particles, suggesting that (1) cell anionogenicity of monocytes from opossum is not due to the presence of acidic specimen from sialic acid or (2) the enzyme despite of being highly purified did not arise the substrate, or (3) the possibility of thin ultrastructural method not being suitable to reveal slight qualitative differences in cell surfaces. The last possibility seems to be true since neuraminidase-treated cells showed themselves less negatively charged when analyzed by measurements of zeta-potential. Therefore, it seems that accessible and for susceptible sialic acid residues are much abundant in adult in macrophage adult than in monocyte cells.

Treatment of eucaryotic cells with neuraminidase reduced or abolished the binding of particles to the cell surface (Pimenta \& De Souza 1982). Mouse peritoneal macrophages showed no effect of the neuraminidase treatment in the pattern of binding of the particles to cell surfaces. The particles were distributed in the cell surface indicating a homogeneous distribution of anionic sites on the cell surface of mouse macrophages (Santos \& De Souza 1983). We observed the same result with the opossum macrophages.

Trypsin is an enzyme that digest proteins. Treatment of the monocytes with trypsin abolished totally or partially binding of cationized ferritin, suggesting that most surface aniogenicity is given glycoproteins. The zeta potential measurements corroborate this ultrastructural finding, since trypsin treated cells from adult animals presented a decrease of up to $65 \%$ in their surface charge.

The enzyme phospholipase $\mathrm{C}$ acts on phosphatidilcholine-rich phospholipids. Although no difference in labelling with cationized ferritin could be observed between normal and phospholipase $\mathrm{C}$ treated cells at the ultrastructural level, the zeta potential measurements showed that the enzyme was effective in digesting anionic surface groups. We believe that both approaches are detecting different anionic groups.

The surface tension of procariotic and eucariotic cells can be estimated by measuring the contact angle formed between the cells and drops of hydrophobic or hydrophilic liquids (vanOss 1978). It has been shown that mammal erythrocytes are highly hydrophilic; and present a higher negative surface charge when compared to other blood cells (vanOss 1978), what makes them highly resistent to phagocytosis by polymorpho-nucleares.
As pointed out by several authors surface tension of phagocytes is a crucial property directly involved in the phagocytic activity of eosinophils, neutrophils and macrophages. Our results of contact angle measurements clearly show that young cells are much more hydrophilic than the adult ones since drops of the high apolar substance abromonaphtalene did spread on cell layers of adult cells. The origin of such surface hydrophobicity is not yet understood. However, it seems that the amount of surface associated oligosaccharide as well as the extension and conformations of the chain may be directly implicated in this property.

Our results demonstrate that in the opossum white blood cells the opposite situation occurs: hidrophobicity is higher in younger animals cells. Other studies are necessary to verify whether this condition applies to other eucariotic white blood cells.

The findings bring new contributions over cell biology of the monocytes of opossum and may contribute for the investigation of the immunological interactions between trypanosomatids and their vertebrate hosts.

\section{ACKNOWLEDGEMENTS}

To Mr Marcos Meuser Batista, Mr Generval Luciano Batista, Mr Antonio Bosco, Mr Carlos Alberto André Ruiz and Mrs Marlene Cazuza for their expert technical assistance.

\section{REFERENCES}

Ackerman GA 1975. Surface differentiation of hemopoietic cells demonstrated ultrastructurally with cationized ferritin. Cell Tiss Res 159: 23-37.

Ambrose EJ 1965. Cell Electrophoresis, Little Brown, Boston, 204 pp.

Brener Z, Chiari E, Alvarenga NJ 1974. Observations on T. cruzi strains maintained over an 8 year period in experimentally inoculated mice. Rev Inst Med Trop São Paulo 16: 32-38.

Cook GMW 1986. Cell surface carbohydrates: molecules in search for a function. J Cell Sci 82 (Suppl. 4): 4570 .

Danon D, Goldstein L, Marikovsky Y, Skutelsky E 1972. Use of cationized ferritin as a label of negative charges on cell surfaces. J Ultrastruct Res 38: 500510.

Feldman DL, Mogelesky TC 1987. Use of Histopaque for isolating mononuclear cells from rabbit blood. $J$ Immunol Methods 102: 243-249.

Gasic GJ, Berwick L, Sorrentino M 1968. Positive and negative colloidal iron as cell surface electron stains. Lab Invest 18: 63-71.

Grinnell F, Anderson RGW, Hackenbrock CR 1976. Glutaraldehyde induced alterations of membrane anionic sites. Biochem Biophys Acta 426: 772-775.

James AM 1979. Molecular aspects of biological surfaces. Chem Soc Rev 8: 389-418. 
Jansen AM, Moriearty PL, Castro BG, Deane MP 1985. Trypanosoma cruzi in the opossum Didelphis marsupialis. An indirect fluorescent antibody test for diagnosis and follow up of natural and experimental infections. Trans $R$ Soc Trop Med Hyg 79: 474-477.

Lamb LS, Willoughby JB, Willoughby F 1995. Morphologic and functional characteristics of alveolar macrophages following cryopreservation. Criobiology 32: 344-357.

Luft JH 1971. Ruthenium red and violet. I. Chemistry, purification, methods of use for electron microscopy and mechanism of action. Anat Rec 171: 347-368.

Mozes N, Rouxhet PG 1987. Methods for measuring hydrophobicity of microorganisms. J Microbiol Meth 6: 99-112.

Mutsaers SE, Papadimitriov JM 1988. Surface charge of macrophages and their interaction with charged particles. J Leukoc Biol 44: 17-26.

Pimenta PFP, De Souza W 1982. Surface charge of eosinophils. Binding of cationic particles and measurement of cellular electrophoretic mobility. Histochemistry 74: 569-576.

Rambourg A 1971. Morphological and histochemical aspects of glycoproteins at the surface of animal cells. Int Rev Cytol 31: 57-114.

Rouxhet PG, Mozes N 1990. Physical chemistry of the interface between attached microorganisms and their support. Wat Sci Tech 22: 1-16.

Santos ABS, De Souza W 1983. Surface charge and ultrastructure of the cell surface of resident and thioglycolate-elicited mouse peritoneal macrophages. J Submicrosc Cytol 15: 897-911.

Silva Filho FC, Santos ABS, de Carvalho TMU, De Souza W 1987. Surface charge of resident, elicited and activated mouse peritoneal macrophages. J Leuk Biol 41: 143-149.

Silva Filho FC, Saraiva EMB, Santos MAV, De Souza W 1990. The surface free energy of Leishmania mexicana amazonensis. Cell Biophys 17: 137-151.

Torroba M, Chiba A, Vicente A, Varas A, Sacedón R, Jimenez E, Honna Y, Zapata AG 1995. Macrophage-lymphocyte cell clusters in the hypothalamic ventricle of some elasmobranch fish: ultrastructural analysis and possible functional significance. The Anatomical Record 242: 400-410.

vanOss CJ 1978. Phagocythosis as a surface phenomenon. Ann Rev Microbiol 32: 19-39. 